\title{
False Negative Results in High Viremia Parvovirus B19-Samples Tested with Real-Time PCR
}

\author{
PIOTR GRABARCZYK*, ALEKSANDRA KALIŃSKA, EWA SULKOWSKA, EWA BROJER \\ Departament of Immunohaematology, Institute of Haematology and Transfusion Medicine, Warsaw, Poland
}

Received 23 September 2009, revised 3 March 2010, accepted 5 March 2010

Abstract

Extremly high viremia is observed during some viruses infection, especialy in immunocompromised patients. False negative results of Parvovirus B19 DNA tests performed with real-time PCR in high viremic samples are reported. The way of fluorescence diagrams analysis and algorithm of positive result confirmation to exclude such phenomenon are proposed.

K e y w ord s: false negative results, real-time PCR, Parvovirus B19

Clinically significant symptoms in Parvovirus B19 (B19V) infected individuals are observed mostly in pregnant women and immunosuppressed patients (Young et al., 2004). The quantitative polymerase chain reaction with product growth analysis in realtime (QPCR) is a commonly used technique, both for clinical diagnosis (Enders et al., 2008; Plentz et al., 2004; Liefeldt et al., 2005) and identification of high levels of this virus in plasma donations to exclude them from plasma pools used for fractionation of plasma derived products (Aberham et al., 2001; Candotti et al., 2004; Aubin et al., 2000; Kleinman et al., 2007; Schmidt et al., 2007; Koppelman et al., 2004). This very sensitive method is used to determine the number of nucleic acid copies of the tested pathogen. The most frequently used variant of this method is based on TaqMan technology with TaqMan probes marked on the $5^{\prime}$ end with reporter dye (e.g. FAM) and on the 3' end with a quencher (e.g. TAMRA). The fluorescence signal is registered from cycle to cycle and the final result is presented as the cycle number $(\mathrm{Ct})$, at which the fluorescence emission crossed the treshold value. Such analysis is performed authomatically. The sample viremia is estimated by comparing the results with the standarization curve plotted from successive dillutions of known viral load (Mackay et al., 2002).
The aim of our study was to present false negative results obtained during quantitative B19V DNA testing of samples with high viral load.

We tested 943 serum samples from patients suspected of B19V infection, directed to the Laboratory of Molecular Biology at the Institute of Haematology and Transfusion Medicine by various haematological, gynecological, reumatological and pediatric clinics.

DNA was isolated with QIAmp DNA Blood Mini Kit (QIAgen, Germany). In the period 2004-2007, DNA isolation was followed by VP1 gene fragment amplification with QPCR performed according to Aberham et al., 2001 (on ABI PRISM 7700, Applied Biosystems, United States and Rotor-Gene 3000, Corbett, Australia). Since 2007, B19V DNA detection was based on the method described by Candotti et al., 2004. The latter test, was performed in duplex format: conservative NS1 gene of B19V was coamplified with human CCR5 gene fragment used as internal control. The former product was detected with FAM labeled probe and the latter, with VIC. The Ct value was used for evaluation of results and it was compared to the standarization curve plotted from successive dillutions of the standard WHO Parvovirus B19 (NIBSC 99/800). The sensitivity of the assays was estimated at 120 and $500 \mathrm{IU} / \mathrm{ml}$ respectively. Anti-B19V antibodies quantitative testing was performed with the

\footnotetext{
* Corresponding author: P, Grabarczyk, Molecular Biology Lab, Departament of Immunohaematology, Institute of Haematology and Transfusion Medicine, 5 ${ }^{\text {th }}$ Chocimska Str., 00-957 Warsaw, Poland; phone: (+48) 223496 600, fax (+48) 223496614 , e-mail: pgrabarczyk@ihit.waw.pl
} 
a
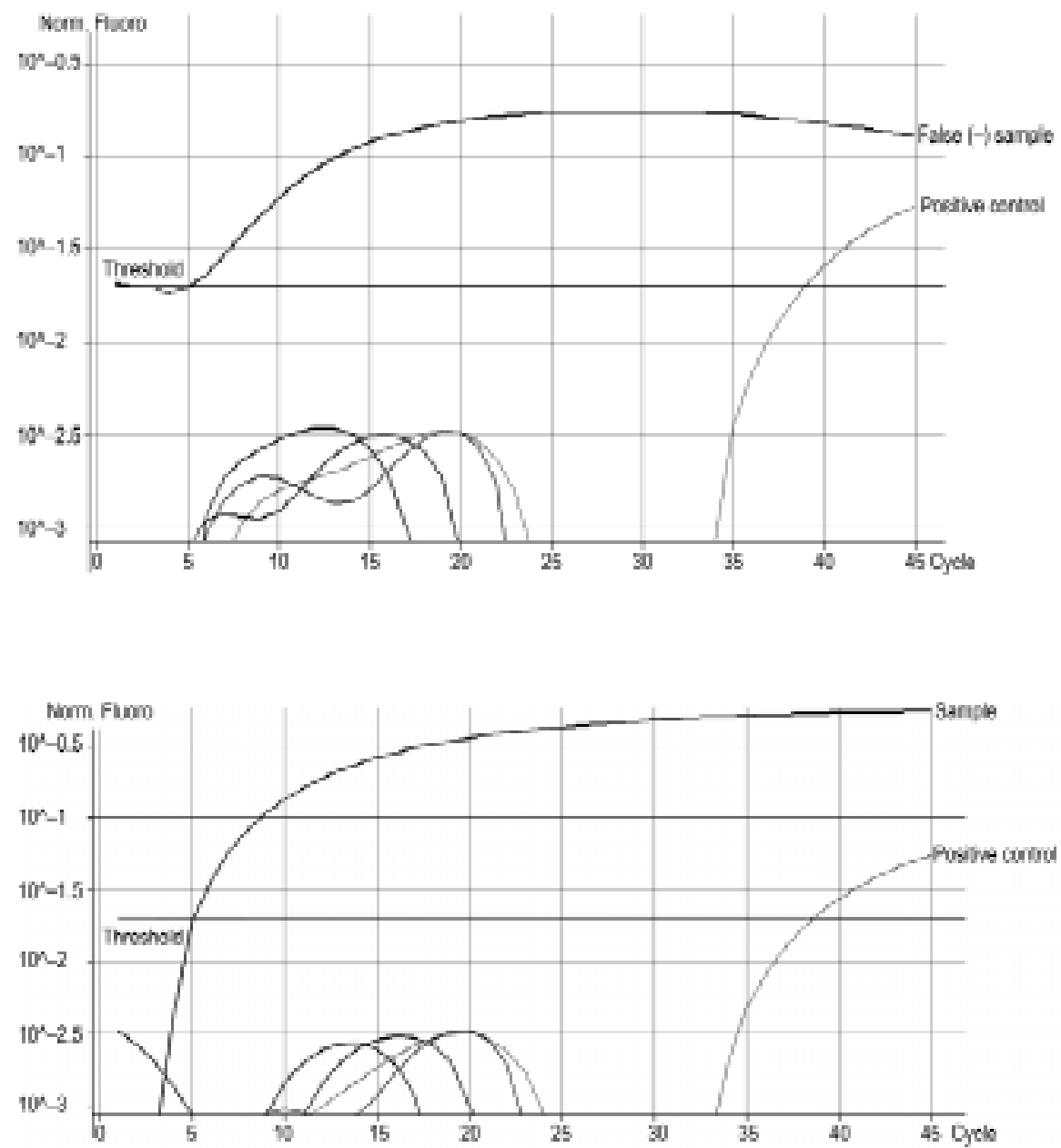

C

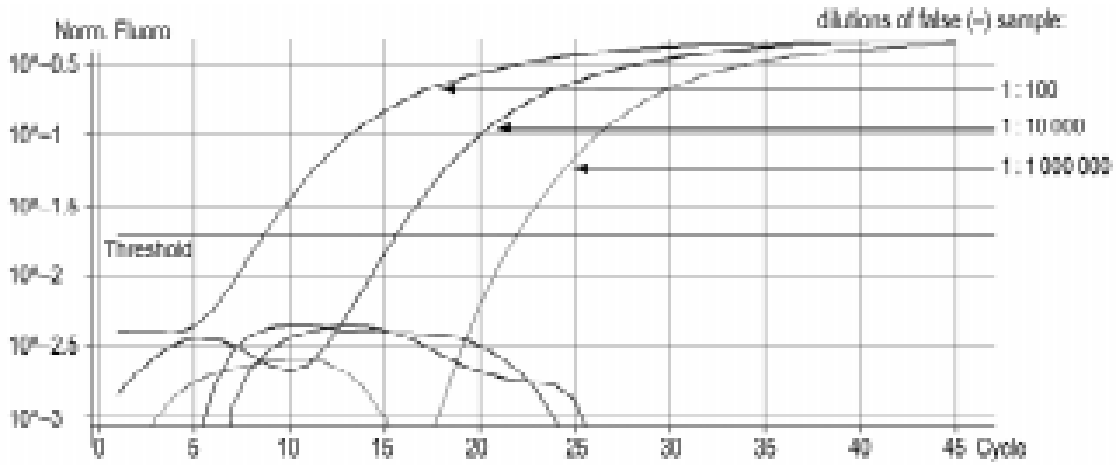

Fig. 1. Fluorescence diagram of FAM probe in false negative B19V DNA sample

- a) automatic data analysis, b) manual data analysis, c) in the dilutions of initially false negative sample.

recom Well Parvovirus B19 IgG/IgM test (Microgen $\mathrm{GmbH}$, Floriansbogen, Germany).

The B19V DNA was detected in 54 patients $(5.7 \%)$ out of the 943 tested serum samples. In four samples ( $7.4 \%$ of all positive results), we obtained negative results during automatic analysis but since the fluorescence course for the FAM probe was atypical, an additional manual analysis was performed. The samples were tested once more using dilluted
DNA. A high B19V DNA level of $9,6 \times 10^{9}$ to over $10^{11} \mathrm{IU} / \mathrm{ml}$ was determined. The EIA testing revealed no specific anti-B19V antibodies in one sample and anti-B19V IgM antibodies in two cases (Table I). The example of results obtained in such procedure was presented on Figure 1. When authomatic analysis was performed, the fluorescence signal of the FAM probe did not exceed the treshold and the $\mathrm{Ct}$ of 45 was initially interpreted as negative B19V DNA 
Table I

Parvovirus B19 DNA concentration and anti-B19V Ig detection in plasma samples with initial false negative B19V DNA results and in follow-up samples.

\begin{tabular}{|c|c|c|c|c|c|c|}
\hline \multirow{3}{*}{$\begin{array}{c}\text { Sample } \\
\text { no }\end{array}$} & \multicolumn{2}{|c|}{$\begin{array}{l}\text { B19V markers } \\
\text { in the index samples }\end{array}$} & \multicolumn{4}{|c|}{ Follow-up results } \\
\hline & \multirow{2}{*}{$\begin{array}{l}\text { DNA } \\
(\mathrm{IU} / \mathrm{ml})\end{array}$} & \multirow{2}{*}{$\begin{array}{c}\text { anti-B19V } \\
\text { IgG/IgM } \\
(\mathrm{U} / \mathrm{ml})\end{array}$} & \multirow{2}{*}{$\begin{array}{c}\text { day of } \\
\text { observation }\end{array}$} & \multirow{2}{*}{$\begin{array}{c}\text { B19V } \\
\text { DNA } \\
(\mathrm{IU} / \mathrm{ml})\end{array}$} & \multicolumn{2}{|c|}{$\begin{array}{l}\text { anti-B19V result } \\
(\mathrm{U} / \mathrm{ml})\end{array}$} \\
\hline & & & & & $\mathrm{IgG}$ & $\operatorname{IgM}$ \\
\hline 725 & $9.6 \times 10^{9}$ & $-/(+)<200$ & $\begin{array}{r}82 \\
245\end{array}$ & $\begin{array}{l}1.3 \times 10^{6} \\
4.7 \times 10^{3}\end{array}$ & $\begin{array}{l}+(136) \\
+(52)\end{array}$ & $\begin{array}{c}+(184) \\
-\end{array}$ \\
\hline 934 & $10^{11}$ & $-1-$ & $\begin{array}{l}26 \\
56\end{array}$ & $\begin{array}{l}2.4 \times 10^{4} \\
9.6 \times 10^{2}\end{array}$ & $\begin{array}{l}\mathrm{nt*} \\
\mathrm{nt} *\end{array}$ & $\begin{array}{l}\mathrm{nt}^{*} \\
\mathrm{nt}^{*}\end{array}$ \\
\hline 213 & $7.5 \times 10^{10}$ & $-/+(107)$ & $\begin{array}{l}10 \\
57\end{array}$ & $\begin{array}{l}2.9 \times 10^{7} \\
4.5 \times 10^{5}\end{array}$ & $\begin{array}{l}+(55) \\
+(85)\end{array}$ & $\begin{array}{l}- \\
-\end{array}$ \\
\hline 91 & $4.2 \times 10^{11}$ & nt* & $\begin{array}{r}3 \\
32 \\
\end{array}$ & $\begin{array}{l}2.3 \times 10^{4} \\
8.1 \times 10^{3}\end{array}$ & $\begin{array}{c}\text { nt* } \\
+(92)\end{array}$ & $\begin{array}{c}\mathrm{nt}^{*} \\
-\end{array}$ \\
\hline
\end{tabular}

* not tested due to shortage of the sample volume or results not informative due to previous immunoglobulin treatment

result (threshold $=0.02$; ignore cycle $=0)($ Figure 1a). The diagram of the fluorescence signal was atypical. The subsequent manual data analysis (threshold $=0.02$; ignore cycle $=4)($ Figure $1 \mathrm{~b})$ showed that the tested sample was positive. The fluorescence diagram exceeded the treshold at $\mathrm{Ct}=5.02$, which points to very high viremia. Real-time PCR testing of the sample performed with DNA in 100, 10000 and 1000000 fold dillutions, confirmed a high B19V DNA concentration (the $\mathrm{Ct}$ values of $8.75 ; 15.69$ and 22.01, respectively, Figure 1c).

The similar results of QPCR analysis were observed for three other samples. In $2 / 2$ samples where simultaneous amplification of the CCR5 constitutive gene was performed, positive result of internal control, (though $\mathrm{Ct}$ value was higher than usual: $\mathrm{Ct}=36$ and $\mathrm{Ct}=40$ ) confirmed that QPCR was properely performed.

All presented patients were monitored for B19V infection markers. In the follow up samples antibodies were detected, accompanied by a decrease of the DNA level.

The fluorescence level diagram for hydrolyzing probe during QPCR is of utmost importance, as shown by the described cases. The linear range for this type of quantitative reading is estimated at $20-10^{9}$ copies $/ \mathrm{ml}$ (Aberham et al., 2001; Candotti et al., 2004). The risk of false negative results can be estimated from the discussed results for B19V DNA tests when the amount of tested DNA exceeds the upper threshold of linearity; in our study, the fluorescence diagram did not cross the threshold. The viremia level was very high, exceeding $10^{9} \mathrm{IU} / \mathrm{ml}$ but we solved the problem of atypical fluorescence diagram interpretation by introducing manual data analysis based on the change of parametr values in the ignore cycle of the Rotor-Gene apparatus and baseline in ABI PRISM. The early crossing point of the fluorescence curve and the threshold ( $\mathrm{Ct}$ value), indicates a high pathogen level of the tested sample and gives ground for repeated QPCR, in a $10^{2}-10^{6}$ fold dilluted samples.

Proper interpretation was so important in the described cases, because serological results for $1 / 3$ of the samples did not point to any infection whatsoever and at this stage only PCR could be used. In addition, the infection was confirmed by B19V markers detection in the follow up samples (Table I).

The conclusions from our study should also be taken into account by laboratories that perform B19V screening in plasma for fractionation and must identify highly vireamic donations; missing of high vireamia donations leads to $\mathrm{B} 19 \mathrm{~V}$ contaminated plasma pools. It is worth noting, that authors who deal with B19V detection in donor populations, report individual viral loads as high as $10^{7} \mathrm{IU} / \mathrm{ml}$ (Kleinman et al., 2007; Aubin et al., 2000) or even $10^{14} \mathrm{IU} / \mathrm{ml}$ (Schmidt et al., 2007; Koppelman et al., 2004).

Very high viremia, especially in the initial infection phase, prior to antibody appearance, is reported by numerous authors to be characteristic not only for B19V but also for other infectious agents (e.g. HBV).

\section{Acknowledgments \\ The authors thank Krystyna Dudziak for help in manuscript preparation.}

\section{Literature}

Aberham C., C. Pendl, P. Gross, G. Zerlauth and M. Gessner. 2001. A quantitative, internally controlled real-time PCR assay for the detection of parvovirus B19 DNA. J. Virol. Method 92: 183-191.

Aubin J.T., C. Defer, M. Viduad, M. Maniez Montreuil and 
B. Flan. 2000. Large-scale screening for human parvovirus B19 DNA by PCR: application to the quality control of plasma for fractionation. Vox Sang. 78: 7-12.

Candotti D., N. Etiz, A. Parsyan and J.-P. Allain. 2004. Identification and characterization of persistent human erythrovirus infection in blood donor samples. J. Virol. 78: 12169-12178.

Enders M., A. Weidner, T. Rosenthal, C. Baisch, L. Hedman, M. Soderlund-Venermo and K. Hedman. 2008. Improved diagnosis of gestational parvovirus B19 infection at the time of nonimmune fetal hydrops. J. Infect. Dis. 1; 197: 58-62.

Kleinman S.H., S.A. Glynn, L. Tzong-Hae, L. Tobler et al. 2007. Prevalence and quantitation of parvovirus B19 DNA levels in blood donors with a sensitive polymerase chain reaction screening assay. Transfusion 47: 1756-64.

Koppelman M.H., H.T.M. Cuypers, T. Emrich and H.L.

Zaaijer. 2004. Quantitative real-time detection of parvovirus B19
DNA in plasma. Transfusion 44: 97-103.

Liefeldt, L., A. Plentz, B. Klempa, O. Kershaw, A.-S. Endres, U. Raab, H-H. Neumayer, H. Meisel and S. Modrow. 2005. Recurrent high level Parvovirus B19/genotype 2 viremia in a renal transplant recipient analysed by real-time PCR for simultaneous detection of genotypes 1 to 3. J. Med. Virol. 75: 161-169.

Mackay I.M., K.E. Arden and A. Nitsche. 2002. Real-time PCR in virology. Nucleic Acid Res. 30: 1292-1305.

Plentz A., J. Hahn, E. Holler, W. Jilg and S. Modrow. 2004 Long-term parvovirus B19 viraemia associated with pure red cell aplasia after allogeneic bone marrow transplantation. J. Clin. Virol. 21: 16-9.

Schmidt M., A. Themann, C. Drexler, M. Bayer, et al. 2007. Blood donor screening for parvovirus B19 in Germany and Austria. Transfusion 47: 1775-1782.

Young N.S. and K.E. Brown. 2004. Mechanisms of disease. Parvovirus B19. N. Engl. J. Med. 350: 586-597. 